\title{
Hand hygiene by the nursing team in home care: a cross-sectional study*
}

\author{
Higienização das mãos pela equipe de enfermagem na atenção domiciliar: \\ um estudo transversal \\ Higienización de las manos por el equipo de enfermería en la atención domiciliar: \\ un estudio transversal
}

How to cite this article:

Cordeiro JFC, Menegueti MG, Laus AM, Tipple AFV, Santana RC, Canini SRMS. Hand hygiene by the nursing team in home care: a cross-sectional study. Rev Esc Enferm USP. 2021;55:e20210104. DOI: https://doi.org/10.1590/1980-220X-REEUSP-2021-0104.

\section{Jéssica Fernanda Corrêa Cordeiro ${ }^{1}$ \\ Mayra Gonçalves Menegueti ${ }^{1}$ \\ Ana Maria Laus ${ }^{1}$ \\ Anaclara Ferreira Veiga Tipple ${ }^{2}$ \\ Rodrigo Carvalho Santana ${ }^{3}$ \\ Silvia Rita Marin da Silva Canini ${ }^{1}$}

* Extracted from the thesis: "Situações de risco para exposição a material biológico por profissionais de enfermagem que atuam na assistência domiciliar de um município do interior paulista”, Universidade de São Paulo, Escola de Enfermagem de Ribeirão Preto, 2018.

${ }^{1}$ Universidade de São Paulo, Escola de Enfermagem de Ribeirão Preto, Ribeirão Preto, SP, Brazil.

${ }^{2}$ Universidade Federal do Goiás, Faculdade de Enfermagem, Goiânia, GO, Brazil.

${ }^{3}$ Universidade de São Paulo, Faculdade de Medicina de Ribeirão Preto, Departamento de Clínica Médica, Ribeirão Preto, SP, Brazil.

\section{ABSTRACT}

Objective: to identify whether nursing professionals carry out hand hygiene, how they do it, and what resources are available for this practice during home visits. Method: cross-sectional study conducted in a public Home Care service. The World Health Organization instrument was used to observe the hand hygiene technique, the time of performance, and the product used. Results: a total of 940 hand hygiene opportunities taking place in 231 home visits were observed. Overall adherence was $14.4 \%$, with the practice of hand hygiene being higher after contact with the patient $(53.7 \%)$. Before aseptic procedures, after risk/exposure to body fluids, after contact with the patient's environment, and before contact with the patient, adherence was $0.4 \%$. Regarding the quality of the technique, in none of the 135 practices the recommended steps were followed. As for the structure available in the households, 35 (15.2\%) had accessible sinks and none had liquid soap and alcohol-based formulation. Conclusion: adherence to hand hygiene by nursing professionals in home care was low, the technique was not performed, and households did not have resources for the practice.

\section{DESCRIPTORS}

Hand Hygiene; Home Nursing; Nursing Care; Patient Safety; Occupational Risks; Infection Control. 


\section{INTRODUCTION}

Among the different adverse events in the health area, Health Care-Associated Infections (HAI) remain frequent, being a worldwide public health problem ${ }^{(1)}$.

Hand hygiene is the simplest and most effective measure to prevent $\mathrm{HAI}^{(2-3)}$. This technique can be performed with soap and water or alcohol-based solution, following the "five moments" recommended by the World Health Organization (WHO), which indicates it before contact with the patient, before aseptic procedures, after contact with bodily fluids, after contact with the patient, and after contact with the patient's environment ${ }^{(4)}$.

Although the importance of this practice is based on strong scientific evidence, studies show that healthcare workers (HCW), especially nursing professionals who have direct contact at care, do not always carry out hand hygiene at the recommended times, with the correct frequency and during the necessary time ${ }^{(5-6)}$.

The adherence of HCWs to hand hygiene has been frequently investigated in hospitals and studies assessing the performance of this procedure in other health care settings are still scarce, even with the expansion of the concept of HAI for health care infections in any care setting ${ }^{(7)}$.

Home care is a health care model that is expanding in several countries and has as one of the central axes the "de-hospitalization" aiming at reducing adverse events, such as $\mathrm{HAI}^{(8)}$, whose magnitude is still little known in this environment ${ }^{(9)}$. The $\mathrm{WHO}^{(10)}$ recommends that $\mathrm{HCW}$ s also carry out hand hygiene in the context of home care and reinforces that direct compliance with this practice constitutes the gold standard for the assessment of adherence to hand hygiene and technical compliance.

On the grounds of the above-mentioned, this study was considered relevant and had as objective to identify whether nursing professionals carry out hand hygiene, how they do it, and what resources are available for this practice during home visits.

\section{METHOD}

\section{Design of Study}

This is a cross-sectional descriptive study with a quantitative approach.

\section{LOCAL}

Conducted in a public Home Care Service (SAD), in the city of Ribeirão Preto, São Paulo, which had its official implementation in 1996. This service hires professionals through a public examination conducted by the city hall.

\section{Population and Selection Criteria}

As recommended in the manual for observers: multimodal strategy, where each team should be observed at least 200 times. Considering that the service has three teams, it would be necessary to observe 600 opportunities for hand hygiene ${ }^{(11)}$. Home visits were carried out by 15 nursing professionals (nursing assistants, nursing technicians, and nurses) working at SAD at the time of collection. The direct observation of home visits was selected, in which there was at least one nursing professional scheduled to perform procedures involving direct contact with patients. Data collection was performed with a single researcher, who was the study's main researcher, carrying out the observations to reduce interpretations and biases.

\section{InSTRUMENTS USED TO COLleCt INFORMATION AND Study VARIables}

Observation was guided by an instrument of public domain from WHO, which was translated into Portuguese. This instrument allowed identifying whether the hand hygiene technique was performed in each of the opportunities and whether soap and water or alcohol-based handrub were used. The moment when the technique was performed was also recorded, according to the five moments proposed by the WHO, that is, before contact with the patient, before aseptic procedures, after exposure to body fluids, after contact with the patient, and after contact with the patient's environment ${ }^{(11)}$.

To measure the quality of the technique, for each hand hygiene opportunity performed, the information about whether all the steps of the technique were performed was registered. The steps defined were: palm/palm; palm/back; interdigital spaces; thumbs; nails, and extremities. In addition, the time to perform the technique was observed, which should be 40 to 60 seconds with soap and water and 20 to 30 seconds with the use of an alcohol-based solution ${ }^{(11)}$. The presence or absence of jewelry was also checked.

To minimize the Hawthorne effect, observations from each team's first 10 home visits were discarded. This strategy was used because when individuals know they are being observed they can change their behavior. However, over time, professionals get used to the observer and start doing the practice in the way they normally do ${ }^{(12)}$.

Besides the instrument for observation of hand hygiene, data on the type of procedure performed in each visit and the physical structure at home for hand hygiene practice were also recorded.

\section{Data Collection}

Data collection began on August 1, 2016 and ended on January 30, 2017. The researcher daily went to SAD and obtained the list of daily visits. To minimize the possible measurement bias that could take place if a professional with greater or lesser adherence to hand hygiene practices was observed more often, an average of 62 opportunities per participant were observed, ranging from 60 to 65 observations. Considering that the team consisted of 15 nursing professionals, a total of 940 opportunities were observed.

\section{Data Analysis and Treatment}

The observations were carried out by a single researcher, the data were entered independently into two Excel spreadsheets and after correction of possible inconsistencies and typing errors, the data were exported to the software IBM 
SPSS Statistics version 21. Data analysis was performed through descriptive statistics, with data presented in absolute and relative frequency.

All opportunities for hand hygiene were computed and a list of adherence rate was elaborated. Thus, the public domain indicator of Adherence to Hand Hygiene Assessment ${ }^{(11)}$ was used, also developed by the WHO, calculated by dividing the number of hand hygiene opportunities used and the total number of opportunities identified, at each moment, multiplied by 100 .

\section{Ethical Aspects}

The study was approved by the Research Ethics Committee of the Nursing School of Ribeirão Preto, under number CAAE 56309960.5.0000.5393 and the research was conducted in accordance with the ethical standards required by Resolution No. 466 of December 2012, of the National Health Council (CONEP). All subjects who agreed to participate in the study signed the Free and Informed Consent Form.

\section{RESULTS}

A total of 940 hand hygiene opportunities taking place in 231 home visits were observed.

Table 1 shows data on hand hygiene before and after direct contact with patients during home visits. These visits were carried out by 15 professionals from the nursing team, over a period of six months. In none of the opportunities observed did the workers sanitize their hands with the correct technique or remove the jewelry.

Table 1 - Distribution of hand hygiene opportunities $(n=462)$ performed by the nursing staff during home visits before and after contact with the patient - Ribeirão Preto, SP, Brazil.

\begin{tabular}{|c|c|c|c|c|}
\hline \multirow{3}{*}{ Variables } & \multicolumn{4}{|c|}{ Hand hygiene } \\
\hline & \multicolumn{2}{|c|}{ Before (231) } & \multicolumn{2}{|c|}{ After (231) } \\
\hline & $\mathbf{n}$ & $\%$ & $\mathbf{n}$ & $\%$ \\
\hline \multicolumn{5}{|c|}{ Hand hygiene } \\
\hline Yes & 11 & 4.8 & 124 & 53.7 \\
\hline No & 220 & 95.2 & 107 & 46.3 \\
\hline \multicolumn{5}{|c|}{ Use of soap and water } \\
\hline Yes & 0 & 0 & 4 & 1.7 \\
\hline No & 231 & 100.0 & 227 & 98.3 \\
\hline \multicolumn{5}{|c|}{ Use of hand sanitizer } \\
\hline Yes & 1 & 0.4 & 83 & 35.9 \\
\hline No & 230 & 99.6 & 148 & 64.1 \\
\hline \multicolumn{5}{|c|}{ Only rinsed with water } \\
\hline Yes & 10 & 4.3 & 35 & 15.2 \\
\hline No & 221 & 95.7 & 196 & 84.8 \\
\hline \multicolumn{5}{|c|}{ Only rinsed with SS $(0.9 \%)$} \\
\hline Yes & 0 & 0 & 2 & 0.8 \\
\hline No & 231 & 100.0 & 229 & 99.2 \\
\hline
\end{tabular}

SS - Saline Solution.
A total of 176 opportunities for hand hygiene were observed before aseptic procedures, such as dressing, blood collection, medication administration, tracheostomy tube change, capillary blood glucose check, diaper change, urine collection by urinary catheter, exchange of indwelling vesical tube and nasoenteral tube. It should be noted that in all these opportunities no hand hygiene took place.

Regarding the opportunities for hand hygiene after contact with the patient's environment, 126 opportunities were registered, none of which with the practice. Table 2 shows the rate of adherence to hand hygiene according to the five moments recommended by the WHO; it should be noted that before performing aseptic procedures, after risk/ exposure to body fluids, and after contact with the patient's environment, the rate of adherence to hand hygiene was null.

As for the quality of the hand hygiene technique performed in 135 opportunities, in none of them did the professional follow all the steps recommended by the WHO, with only the palm-palm and palm-back movements being performed. No worker performed the technique within the recommended time, neither with soap and water nor with an alcohol-based formulation.

When observing the structure available for hand hygiene at the households, 35 (15.2\%) had sinks accessible to workers and none of them had liquid soap, alcohol-based formulation, and/or paper towels available. The workers had hand sanitizer among the materials/work inputs that they took to the homes in a bag; however, it was not always used, as mentioned in Tables 1 and 2.

\section{DISCUSSION}

Hand hygiene in out-of-hospital services remains an important challenge for healthcare workers who provide assistance in this settings. The present study identified, through direct observation, that hand hygiene by nursing professionals during home care was well below 100\%, which is considered the ideal rate, both in opportunities before

Table 2 - Hand hygiene adherence rate according to the five moments recommended by the World Health Organization Ribeirão Preto, SP, Brazil.

\begin{tabular}{lccc}
\hline $\begin{array}{l}\text { Time } \\
\text { recommended by } \\
\text { WHO }\end{array}$ & $\begin{array}{c}\text { Number of } \\
\text { opportunities } \\
\text { observed }\end{array}$ & $\begin{array}{c}\text { Hand hygiene } \\
\text { performed }\end{array}$ & $\begin{array}{c}\text { Adherence rate } \\
\text { (percentage) }\end{array}$ \\
\hline $\begin{array}{l}\text { Before contact } \\
\text { with the patient }\end{array}$ & 231 & 11 & 4.8 \\
$\begin{array}{l}\text { After contact with } \\
\text { the patient }\end{array}$ & 231 & 124 & 53.7 \\
$\begin{array}{l}\text { Before performing } \\
\text { aseptic } \\
\text { procedures }\end{array}$ & 176 & 0 & 0 \\
$\begin{array}{l}\text { After risk/ } \\
\text { exposure to body } \\
\text { fluids }\end{array}$ & 176 & 0 & 0 \\
$\begin{array}{l}\text { After contact } \\
\text { with the patient's } \\
\text { environment }\end{array}$ & 126 & 0 & 0 \\
$\begin{array}{l}\text { Total of } \\
\text { opportunities }\end{array}$ & 940 & 135 & 14.4 \\
\hline
\end{tabular}


contact with the patient, 11 (4.8\%), as for opportunities after contact, 124 (53.7\%). This technique is considered one of the simplest and most effective measures for the prevention and control of HAIs and also an important measure to prevent professionals from contracting pathogens and consequently developing infections ${ }^{(7)}$.

HAIs can have a major impact on patients receiving care. A study analyzing 199,462 patients treated in home care showed that $3.5 \%$ of them developed infections that consequently accounted for an increase in emergency care and also for an increase in hospitalizations ${ }^{(13)}$.

A study carried out in Sweden ${ }^{(14)}$, which analyzed, through secondary data, 356 adverse events related to health care, showed that 271 of them $(76.1 \%$; $95 \%$ CI $67.5-85.6)$ were related to home care and $255(71.4 \%, 95 \% \mathrm{CI}-60.9$ to 78.2) were evaluated as avoidable, with HAI being among the most frequent.

The best adherence rate in this study was related to the moment after contact with the patients, which was also observed in a household study ${ }^{(15)}$ that identified that hand hygiene occurred in only $21.5 \%$ of the opportunities before the visits and $61.8 \%$ after them. The highest rates of hand hygiene were after the visit and show the workers' greater concern with their own safety rather than the patient's safety.

Hand hygiene with soap and water was performed in only $04(1.74 \%)$ opportunities after contact with the patient, which can be easily explained by the unavailability of access to this resource in many households. The use of alcoholbased solutions was observed in only one ( $0.4 \%)$ opportunity before contact and in 83 (35.9\%) after contact. It should be noted that the use of alcohol-based solutions has been strongly encouraged given the strong evidence of their effectiveness, ease of use, shorter application time, and greater skin tolerance as they cause less irritation ${ }^{(16-17)}$. However, when the service takes place at home, the professional is required to take the product for this purpose and use it properly. The use of alcohol-based solutions, in addition to the benefits described, can favor the practice of hand hygiene, except in the presence of visible dirt or after exposing the hands to body fluids. In these situations, hand hygiene with soap and water is mandatory ${ }^{(10)}$.

According to the $\mathrm{WHO}$ guidelines ${ }^{(10)}$, for hand hygiene in out-of-hospital care, the five essential moments for carrying out this practice shall be maintained.

In the present study, it was observed that in the rare moments when there was adherence to hand hygiene, all professionals remained with their jewelry and did not perform the technique correctly, contrary to the recommendations of important national and international agencies ${ }^{(10-11,17)}$.

Regarding the quality of the hand hygiene technique, in the present investigation, it was observed that none of the visits were performed correctly by the workers. In an observational study in six intensive care units of six hospitals in Central and Northern Italy, which observed the technique of hand washing, ICU workers, showed high adherence in all phases of the hand washing process, even though we have found variability among units (ranging from $47.6 \%$ to 100.0\%). Poor adherence (ranging from $3.1 \%$ to $5 \%$ ) was found in relation to the use of a towel to close the tap after washing hands with soap and water ${ }^{(18)}$. Differing from what was observed in the present study, in which no worker performed any of the techniques steps correctly, the difference between the research settings is also highlighted.

Effective continuous hand hygiene practice is a simpler way to prevent HAIs. For proper hand hygiene to take place, the worker is affected by a series of factors, such as precise knowledge, correct decontamination technique, human factors, the environment, and effective leadership. Moreover, without the proper technique recommended, hand hygiene loses its proper effectiveness ${ }^{(19)}$.

It should be noted that in 35 (15.2\%) visits, the home had accessible sinks and none of them had liquid soap, hand sanitizer, and/or paper towels available, which reinforces the need for systemic changes to increase adherence to hand hygiene in out-of-hospital care.

The need for early discharge and reduced costs with hospital care has increasingly transferred complex care and invasive procedures to an unfavorable setting, hindering the performance of health care workers and directly impacting the conditions for hand hygiene. Of the 940 hand hygiene opportunities identified, 176 referred to aseptic, invasive procedures or those with risk of exposure to biological material. This situation shows the importance of elaborating specific protocols for carrying out hand hygiene and HAI prevention measures at home, as well as disclosing and enabling the use of alcohol-based solution to carry out hand hygiene in home care.

Adherence data were identified by an observational study conducted in a certified non-profit home health agency in the United States, which described nurses' hand hygiene practices in the home care environment, nurses' adherence to hand hygiene guidelines, and factors associated with hand hygiene opportunities during home visits. In all, 2014 opportunities were observed. The most frequent opportunity was on arrival at home $(n=384)$, the least frequent was after touching near the patient $(n=43)$. The mean rate of adherence to hand hygiene was $45.6 \%$ after adjusting for grouping at the nursing level. Adherence was higher after contact with bodily fluids $(65.1 \%)$ and lower after touching a patient $(29.5 \%)^{(20)}$.

One of the possible limitations of the study would be the possibility for professionals to modify their behavior due to the presence of a researcher directly observing the practice of hand hygiene at home and also because they knew that they would be observed, since they were previously approached and clarified about the objective of the study. However, it is believed that discarding the first 10 visits may have minimized this effect.

Despite having some limitations, the study allowed us to draw an overview of how hand hygiene is performed by nursing professionals in home care. The data obtained can support the proposition of educational measures to increase adherence rate and improve the implementation of the hand hygiene technique, since it was identified that the workers perform more hand hygiene after home visits, showing a 
greater concern with their risk of contamination rather than with the patient's risk.

\section{CONCLUSION}

It is concluded that the adherence to hand hygiene by nursing professionals in the home care setting was low and in the opportunities in which the technique was performed, the quality of the technique was not met. In addition, it was observed that the households did not have resources/ structure to carry out this practice.
Home care is a model in full expansion in the country; however, the characteristics of the houses differ from hospital care, which has its structure organized to facilitate the performance of the nursing team with greater safety. Workers also need more continuing education to consider hand hygiene an essential practice for their work. Therefore, home care needs to be better investigated; also, new policies and manuals should be aimed at adapting strategies to improve hand hygiene by the nursing staff at this level of care.

\section{RESUMO}

Objetivo: identificar se os profissionais de enfermagem realizam a higienização das mãos, como fazem e quais os recursos disponíveis para essa prática durante visitas domiciliares. Método: estudo transversal conduzido num serviço público de Atenção Domiciliar. Utilizou-se o instrumento da Organização Mundial da Saúde para as observações da técnica de higiene de mãos, momento de realização e produto utilizado. Resultados: foram observadas 940 oportunidades de higienização de mãos que aconteceram em 231 visitas domiciliares. A adesão global foi de 14,4\%, sendo que a prática de higiene de mãos foi maior após o contato com o paciente (53,7\%). Nos momentos anteriores aos procedimentos assépticos, após risco/exposição a fluidos corpóreos, após contato com o ambiente do paciente e antes do contato com o paciente a adesão foi de $0,4 \%$. Em relação à qualidade da técnica, em nenhuma das 135 práticas houve o seguimento de todos os passos recomendados. Quanto à estrutura disponível nos domicílios, 35 (15,2\%) apresentavam pias acessíveis e em nenhum havia sabão líquido e formulação alcoólica. Conclusão: a adesão a higiene de mãos por profissionais de enfermagem na atenção domiciliar foi baixa, a técnica não foi atendida e os domicílios não apresentaram recursos para a execução dessa prática.

\section{DESCRITORES}

Higiene das Mãos; Assistência Domiciliar; Cuidados de Enfermagem; Segurança do Paciente; Riscos Ocupacionais; Controle de Infecções.

\section{RESUMEN}

Objetivo: identificar si los profesionales de enfermería realizan el lavado de las manos, cómo lo hacen y cuáles son los recursos disponibles para esa práctica durante la realización de visitas domiciliares. Método: estudio transversal realizado en un sector público de Atención Domiciliar. Se utilizó el instrumento de la Organización Mundial de la Salud, para las observaciones de la técnica de higienización de las manos, su momento de realización y producto utilizado. Resultados: fueron observadas 940 oportunidades de higienización de las manos que ocurrieron en 231 visitas domiciliares. La adhesión global fue un 14,4\%, una vez que la práctica de higiene de manos se incrementó tras el contacto con el paciente (53,7\%). En los momentos antes de los procedimientos asépticos, tras riesgo/exposición a fluidos corporales, tras el contacto con el ambiente del paciente y antes del contacto con él, la adhesión fue 0,4\%. En relación a la calidad de la técnica, en ninguna de las 135 prácticas se han seguido todas las etapas recomendadas. En relación a la estructura disponible en los domicilios, 35 de ellos $(15,2 \%)$ presentaban lavabos accesibles y en ninguno había jabón líquido y soluciones hidroalcohólicas. Conclusión: la adhesión a la higienización de las manos por profesionales de enfermería en la atención domiciliar fue baja, la técnica no fue seguida y los domicilios no presentaron recursos para la ejecución de esa práctica.

\section{DESCRIPTORES}

Higiene de las Manos; Atención Domiciliaria de Salud; Atención de Enfermería; Seguridad del Paciente; Riesgos Laborales; Control de Infecciones.

\section{REFERENCES}

1. Brasil. Ministério da Saúde. Agência Nacional de Vigilância Sanitária (BR). Resolução RDC n 36, de 25 de julho de 2013 . Institui ações para a segurança do paciente em serviços de saúde e dá outras providências. [Internet]. Brasília; 2013 [cited 2021 Jan. 20]. Available from: https://bvsms.saude.gov.br/bvs/saudelegis/anvisa/2013/rdc0036_25_07_2013.html

2. Baccolini V, D'Egidio V, De Soccio P, Migliara G, Massimi A, Alessandri F, et al. Effectiveness over time of a multimodal intervention to improve compliance with standard hygiene precautions in an intensive care unit of a large teaching hospital. Antimicrob Resist Infect Control. 2019;8:92. DOI: http://dx.doi.org/10.1186/s13756-019-0544-0.

3. Aguiar PD, Mouta AAN, Alves ARR, de Almeida FCR, da Silva ACB, Lopes PF, et al. The importance of hand hygiene in intensive care units: the dangers of healthcare-related infections Revista Eletrônica Acervo Saúde, 2020;12(9):e3854. DOI: http://dx.doi.org/10.25248/ reas.e3854.2020.

4. World Health Organization \& World Alliance for Patient Safet. Summary of the evidence on patient safety: implications for research: the research priority setting working group of the World Alliance for Patient Safety. Geneva: World Health OrganizationWorld [Internet]. 2008 [cited 2021 Feb. 20]. Available from: https://apps.who.int/iris/bitstream/handle/10665/43874/9789241596541_eng. pdf? sequence $=1$ \&isAllowed $=y$

5. Raimondi DC, Bernal SCZ, Souza VS, Oliveira JLC, Matsuda LM. Higienização das mãos: adesão da equipe de enfermagem de unidades de terapia intensiva pediátricas. Rev Cuid. 2017;8(3):1839-48. DOI: http://dx.doi.org/10.15649/cuidarte.v8i3.437.

6. Hammerschmidt J, Manser T. Nurses' knowledge, behaviour and compliance concerning hand hygiene in nursing homes: a cross-sectional mixed-methods study. BMC health services research, 2019;19:547. DOI: http://dx.doi.org/10.1186/s12913-019-4347-z.

7. Zottele C, Magnago TSBS, Dullius AIS, Kolankiewicz ACB, Ongaro JD. Hand hygiene compliance of healthcare professionals in an emergency department. Rev Esc Enferm USP. 2017;51:e03242. DOI: http://dx.doi.org/10.1590/S1980-220X2016035503242. 
8. BRASIL. Portaria n 825, de 25 de abril de 2016. Redefine a Atenção Domiciliar no âmbito do Sistema Único de Saúde (SUS) e atualiza as equipes habilitadas. [Internet União Brasília; 2016. [cited 2020 Dec. 15]. Available from: https://www.in.gov.br/materia/-/asset_publisher/ Kujrw0TZC2Mb/content/id/22685962/do1-2016-04-26-portaria-n-825-de-25-de-abril-de-2016-22685827.

9. Martos-Cabrera MB, Mota-Romero E, Martos-García R, Gómez-Urquiza, JL, Suleiman-Martos N, Albendín-García, L. Hand Hygiene Teaching Strategies among Nursing Staff: A Systematic Review. International journal of environmental research and public health, 2019;16(17):3039. DOI: http://dx.doi.org/10.3390/ijerph16173039.

10. OMS. [Internet]. Salve Vidas: Higienize suas Mãos/Higiene das Mãos na Assistência à Saúde Extra-hospitalar e Domiciliar e nas Instituições de Longa Permanência. [cited 2020 dec. 15]. Organização Mundial da Saúde. Available from: https://proqualis.net/sites/proqualis.net/ files/Manual\%20HM\%20OMS\%20extra\%20hospitalar\%202014.pdf.

11. Brasil. Organização Pan-Americana da Saúde, Agência Nacional de Vigilância Sanitária. Manual para observadores: estratégia multimodal da OMS para a melhoria da higienização das mãos. 2008. [cited 2020 dec. 20]. Available from: https://www.anvisa.gov.br/servicosaude/ controle/higienizacao_oms/manual_para_observadores-miolo.pdf.

12. Kurtz SL. Identification of low, high, and super gelers and barriers to hand hygiene among intensive care unit nurses. Am J Infect Control. 2017;45(8):839-43. DOI: http://dx.doi.org/10.1016/j.ajic.2017.04.004.

13. Shang ELJ, Liu PSJ. Infection in home health care: Results from national Outcome and Assessment Information Set data. Am J Infect Control. 2015;43(5):454-459. DOI: http://dx.doi.org/10.1016/j.ajic.2014.12.017.

14. Schildmeijer KGI, Unbeck M, Ekstedt M, Lindblad M, Nilsson L. Adverse events in patients in home healthcare: A retrospective record review using trigger tool methodology. BMJ Open. 2018;8:e019267. DOI: http://dx.doi.org/10.1136/bmjopen-2017-019267.

15. Figueiredo RM, Maroldi MAC. Home care: Health professionals at risk for biological exposure. Rev da Esc Enferm. 2012;46(1):145-5. Available from: https://www.scielo.br/pdf/reeusp/v46n1/en_v46n1a20.pdf.

16. Stadler RN, Tschudin-Sutter S. What is new with hand hygiene? Curr Opin Infect Dis. 2020;33(4):327-332. DOI: http://dx.doi.org/10.1097/ QCO.0000000000000654.

17. Centers for Disease Control and Prevention (CDC) [Internet]. CDC Statement for Healthcare Personnel on Hand Hygiene during the Response to the International Emergence of COVID-19. 2020. [cited 2021 Jan. 10]. Available from: https://www.cdc.gov/coronavirus/2019ncov/infection-control/hcp-hand-sanitizer.html.

18. Musu M, Lai A, Mereu NM, Galletta M, Campagna M, Tidore M, Coppola RC. Assessing hand hygiene compliance among healthcare workers in six Intensive Care Units. Journal of preventive medicine and hygiene, 2017;58(3):E231-E237.

19. Hillier MD. Using effective hand hygiene practice to prevent and control infection. Nurs Stand, 2020;35(5):45-50. DOI: http://dx.doi. org/10.7748/ns.2020.e11552.

20. McDonald MV, Brickner C, Russell D, Dowding D, Larson EL, Trifilio M, Bick IY, Sridharan S, Song J, Adams V, Woo K, Shang J. Observation of Hand Hygiene Practices in Home Health Care. 2020;15;S1525-8610(20)30656-3. DOI: http://dx.doi.org/10.1016/j. jamda.2020.07.031. 